\title{
Chondroid Syringoma: A case with unusual localization
}

\author{
Chondroid Syringoma: Nadir lokalizasyonlu bir olgu
}

Serdar Yüce, Mustafa Öksüz, Yılmaz Sultanoğlu, Muhammet Eren Ersöz, Yavuz Özsular

\begin{abstract}
Chondroid syringoma is a skin tumour with benign character that is named as mixcutaneous tumour. Chondroid syringoma grows slowly without pain and ulcer and is seen as subcutaneous or intracutaneous in $0.5-3 \mathrm{~cm}$ size. Chondroid syringoma is generally seen in middle age and old men in head and neck region. It can rarely trunk, back, extremities and genital organs. Since chondroid syringoma is a benign lesion, it was reported in malign and atypic forms. The most important clinical finding of malign tumours is a rapid growing bulk. Malign chondroid syringoma is generally seen in young female patients in body and extremity localizations. Because of malign transformation, potential, total excision is the preferred treatment in benign chondroid syringomas. Despite being rare lesions, in subcutaneous nodules in body and extremities, particularly in head and neck region, chondroid syringoma should be thought. In this study, benign a case chondroid syringoma locating in extremity of young female patient was presented. J Clin Exp Invest 2014; 5 (3): 441-443
\end{abstract}

Key words: Chondroid syringoma, benign, extremity

\section{INTRODUCTION}

Chondroid syringoma which originates from rarely seen eccrine sweat glands, is a mix skin tumour with epithelial and mesenchymal origin that was defined firstly by Billorth in 1859 [1-3]. The frequency of Chondroid syringoma was found as between $0.01 \%$ and $0.1 \%$ in various series [4-7]. Benign form is generally seen in head and neck regions whereas rarely seen in extremities $[1,8,9]$. In contrast malign chondroid syringoma is mostly seen in extremities and characterised with rapid growth, local invasion and far metastasis [1,9]. Benign chondroid syringoma shows symptomatic progress in long term.

\section{ÖZET}

Chondroid syringoma miks kutanöz tümör olarak adlandırılan benign karakterde bir cilt tümörüdür. Chondroid syringoma klinik olarak yavaş büyüyen, ağrısız, ülsere olmayan, subkutanöz veya intrakutanöz 0,5 ila $3 \mathrm{~cm}$ arasında boyutlara sahip nodul şeklinde görülür. Chondroid syringoma genellikle baş boyun bölgesinde orta yaş ve yaşlı erkeklerde görülür. Nadir olarak gövde, sırt, ekstremiteler ve genital organları tutabilir. Chondroid syringoma benign lezyon olmasına rağmen malign ve atipik formlarda rapor edilmiştir. Malign tümörlerin en önemli klinik bulgusu kısa zamanda hızlı büyüyen kitle olmasıdır. Malign chondroid syringoma genellikle genç bayan hastalarda, gövde ve ekstremite lokalizasyonlarında görülür. Malign dönüşüm potansiyelinden dolayı benign chondroid syringomalara total eksizyon tercih edilen tedavi şeklidir. Nadir lezyonlar olmasına rağmen, baş boyun bölgesi başta olmak üzere gövde ve ekstremitelerdeki subkutanöz nodüllerde chondroid syringoma akla getirilmelidir. Bu çalışmada, genç bayan hastada ekstremite yerleşimli benign bir chondroid syringoma olgusu sunulmuştur.

Anahtar kelimeler: Chondroid syringoma, selim, ekstremite

In this study a benign chondroid syringoma locating in extremity in young female patient case was presented.

\section{CASE}

26 year old female patient applied for a complaint of a painless bulk in the right arm. The lesion was firstly appeared 5 years ago and in the last 2 years it has a growing progress. In the physical examination, there obtained a hard mobile subcutaneous bulk with $3.5 \times 2 \mathrm{~cm}$ size in antecubital fossa inferolateral of right forearm (Figure 1). At the end of USG $30 \times 14 \mathrm{~mm}$ size heterogenic lesion with

Yüzüncü Yıl Üniversitesi, Tıp Fakültesi, Plastik, Rekonstrüktif ve Estetik Cerrahi Anabilim Dalı Van, Türkiye

Correspondence: Serdar Yüce,

Yüzüncü Yıl Üniversitesi, Tıp Fakültesi, Plastik Cer. A.D. 65100, Van, Türkiye Email: yuceserdar23@yahoo.com

Received: 21.04.2014, Accepted: 22.05.2014

Copyright @ JCEI / Journal of Clinical and Experimental Investigations 2014, All rights reserved 
lobule contour which its bound can be identified clearly, its central is more echogenic and does not have a clear blood build up, was observed. Due to the growing progress and localisation of lesion, total excision was planned. The excision was done under local anaesthesia and $3 \times 2 \times 1 \mathrm{~cm}$ size, white, par- tially capsulated and nodular lesion was taken out (Figure 2). At the end of histopathological evaluation was identified as benign skin tumour in accordence with mix tumour (chondroid syringoma). In the post operative follow ups of patient any recurrence and complication was not observed.

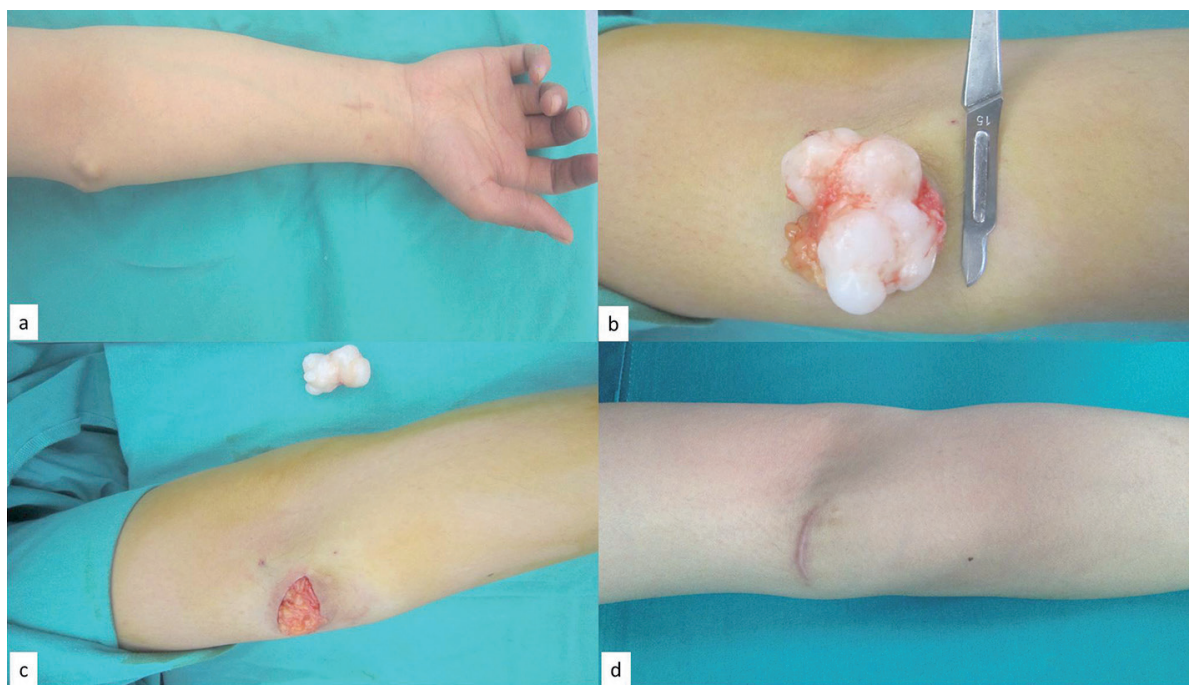

Figure 1. (a) Preoperative appearance of lesion on the extremity, (b) Intraoperative appearance of the during excision, (c) Intraoperative appearance of the after excision, (d) Postoperative appearance of the early result

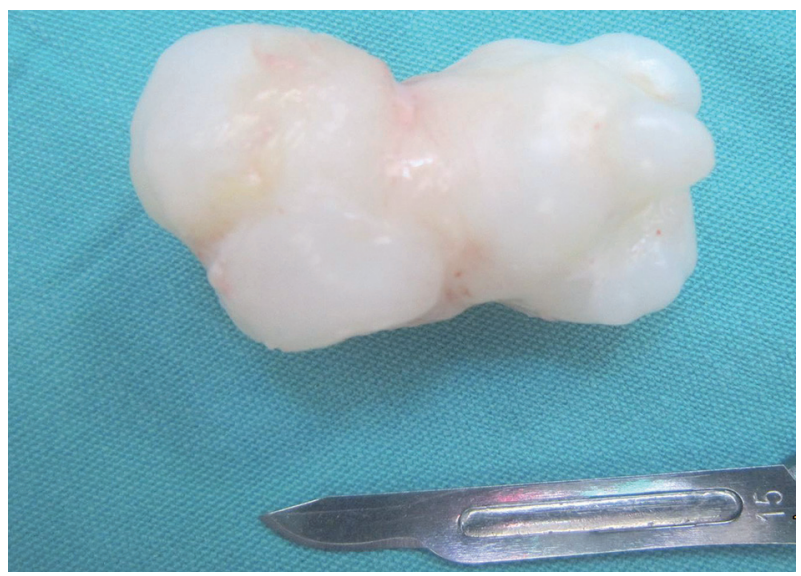

Figure 2. Postoperative appearance of the lesion

\section{DISCUSSION}

Chondroid syringoma is a benign characterised skin tumour that is named as mixed cutaneous tumour due to the existence of epithelial and mesenchymal components [9]. It was defined by Billroth in 1859 and histopathologically it has similar properties of benign mix tumour of salivary glands. In $1961 \mathrm{Hirsch}$ and Helwing defined this tumour as chondroid syringoma and it is characterised with the existence of sweat gland elements in stroma similar to cartilage $[4,6,7,9]$.
Chondroid syringoma grows clinically slow and is seen as painless, nonulcerated, subcutaneous or intracutaneous nodule with a size between 0,5 and $3 \mathrm{~cm}[3,4,6]$. It generally fixes on the skin whereas it does not fix on deep subcutaneous tissues [4]. Chondroid syringoma is generally seen in head and neck region of middle age and old men $[3,4,6,9]$. The tumour in head and neck region frequently affects nose, cheek and upper lip, however at the same time scalp, forehead, brow and upper eyelid can be affected [4]. Rarely it can hold on trunk, back, extremities and genital organs [3,4,9]. Since Chondroid syringoma is a rare tumour, it is not usually considered. In differential diagnosis nevus, epidermal, sebaseous cyst, dermoid cyst, neurofibroma, dermatofibroma, schwannoma, pilomatricoma and histiocytoma should be taken into consideration $[3,4,10]$. Chondroid syringoma lesions are not generally obvious and excisional biopsy and microscopic treatment is necessary for diagnosis [3].

Although Chondroid syringoma is a benign lesion, it was reported in malign and atypic forms. In malign chondroid syringoma de novo can occur after recurrence and malign transformation $[1,4]$. The most important clinical finding of malign tumours is they grow rapidly in short time [1]. Malign chondroid syringoma is generally seen in trunk and extremity localisations in young female patients. The tumour 
is generally bigger than $3 \mathrm{~cm}$ and shows local invasive property $[3,7,9,10]$. Malign chondroid syringoma shows hematogenous and lympathic metastasis. Common metastatic regions are lymph nodes, lung and bone [4]. For malign tumours lymph node dispersion incidence is approximately $48 \%$ however the risk of metastasis is $45 \%$ [1]. The histopathologic properties of malign chondroid syringoma are similar with benign and some of them does not have an eliminating property $[1,3]$.

There are multiple treatment methods; electrodessication, dermabrasion, and vaporization with argon or Co2 laser, usual first-line treatment of the tumor is total excision $[3,6,10]$. Because of malign transformation potential, total excision is the preferred treatment method for benign chondroid syringomas [1]. Chondroid syringoma is a benign tumour and no recurrence is observed in case of complete excision is done [3]. Histopathologically for malign and big tumours (for example bigger than $3 \mathrm{~cm}$ ) in order to avoid local recurrency there needs excision with $1 \mathrm{~cm}$ security margin. Lymph node dissection is done in palpable lymph node or in clinical suspect facts $[1,3]$.

As a result, despite they are rare lesions, Chondroid Syringoma should be taken into consideration in subcutaneous nodes in body and extremities especially in head and neck region. In risky situations relating with malign form like atypic localisation, rapid progress, young female patient it should be put under control with complete excision and close follow up.

\section{REFERENCES}

1. Sirinoğlu H, Ersoy B, Tezel E. Benign chondroid syringoma: atypical presentation of a rare eccrine tumor. $J$ Foot Ankle Surg 2011;50:364-366.

2. Skeikh SS, Pennanen M, Montgomery E. Benign chondroid syringoma: report of a case clinically mimicking a malignant neoplasm. J Surg Oncol 2000;73:228-230.

3. Sirivella S, Gielchinsky I. Chondroid syringoma: a rare tumor of the chest wall. Ann Thorac Surg 2010;89:983985.

4. Gündüz K, Demirel S, Heper AO, Günalp I. A rare case of atypical chondroid syringoma of the lower eyelid and review of the literature. Surv Ophthalmol 2006;51:280-285.

5. Kitazawa T, Hataya Y, Matsuo K: Chondroid syringoma of the orbit. Ann Plast Surg 1999;42:100-102.

6. Yavuzer R, Başterzi Y, Sari A, et al. Chondroid syringoma: a diagnosis more frequent than expected. Dermatol Surg 2003;29:179-181.

7. Kakitsubata Y, Theodorou SJ, Theodorou DJ, et al. Giant chondroid syringoma presenting as a growing subcutaneous mass in the upper arm: MRI findings with pathologic correlation. Joint Bone Spine 2009;76:711-714.

8. Borman H, Deniz M, Ertas NM, et al . Chondroid syringoma of the hand. Scand J Plast Reconstr Surg Hand Surg 2009;43:291-293.

9. Franco JP, Zacaron LH, Lima RB, D'Acri AM, Martins CJ. Case for diagnosis. Chondroid syringoma. An Bras Dermatol 2013;88:997-999.

10. Narasimha A, Kalyani R, Kumar HM, et al. Giant chondroid syringoma with divergent differentiation: Cytohisto-immuno correlation. Int J Appl Basic Med Res 2013;3:129-131. 